\title{
INFORMATION AND COMMUNICATION \\ LITERACY AMONG PRACTISING LIBRARIANS IN DELTA STATE
}

\author{
BY \\ M. U. UGBOMA (MRS) \\ DELTA STATE UNIVERSITY \\ OLEH CAMPUS. \\ EMAIL: Megugboma@yahoo.com \\ MOBILE PHONE: 08020745956
}

\begin{abstract}
This study was designed to ascertain the level of ICT literacy among practicing librarians in Delta State, Nigeria. A survey involving 104 practicing librarians was conducted. The 104 librarians work in academic, public and special libraries.On a self-assessment basis, respondents revealed that they were more familiar with, and constantly used communication models of mobile telephony $100 \%$, electronic-mail, $65 \%$ than other forms of communication like on-line $19 \%$ and fax $27 \%$. Data also revealed that respondents were familiar with and used the internet but outside official duties. The study therefore concludes that practicing librarians in the State are yet to be fully ICT literate. Recommendations for improvements are also made.
\end{abstract}

\section{INTRODUCTION}

Librarians are traditionally information brokers. They deal with the packaging and dissemination of information for peoples in the society. The need for the recognition and use of information by all sectors of the society has always been of paramount interest to the practicing Librarian with the result that they are always in the vanguard for the creation of awareness of information need, access and utilization.

Book fairs, workshops/seminars readership campaigns are some of the strategies that had been employed in the past to create an informed society. In the recent times, campaigns for the use of ICT have been added and in Nigeria, this campaign started in-house, that is; among and for the Librarians themselves. This is evident from the themes of Conferences and Annual General Meetings of the Nigerian Library Association 2001, which since has been strengthening libraries and Librarians for new information age through ICT. It is obvious that Librarians are conscious of the need for them to acquire ICT knowledge in order to function effectively in the new age.

According to Nweke (1992), knowledge has developed to such an extent that it is practically impossible for library users to be conversant with all aspects of their field of specialization and interests and according to Ifidon (2003), for any one library to function effectively based only on the physical materials in its library. It becomes imperative therefore, that Librarians need to use ICT in the discharge of their duties which is; matching information to users. Much more than before, information seeking process transcends the simple Librarian-client relationship of question and answer to involve a whole new, more complex process of advisory, search, retrieval and delivery (Madu and Adeniran, 2000).

In Nigeria, the consciousness of ICT has caught on. By 1987, only five institutions and information and documentation centres were identified to have some form of ICT. Ubogu and Gupta (1987). Today however, many Universities and other information centres apply ICT to their operations and services. Ifidon (2003) also reveal that many Internet Service Providers also operate ICT services within and outside Campuses and in other towns and cities in the country. Adeyoyin (2005) however, observed that though the situation has improved, there are still impediments that hamper the full exploitation of ICT. As reported in findings of Adeyoyin's (2005) survey of eighteen Nigerian Universities, a lot is yet to be done to breech the gap between desired levels of ICT literacy and the actual levels. 


\section{LITERATURE REVIEW}

The successful manipulation of computer for communication and information services is the basis for the new vista in library and information services of today. The result is complete transformation of the entire structure of information provision and telecommunication. Packaging, accessing and delivery of information is handled with the aid of computer networks for speed, accuracy and reach. Telecommunications also have new creation of the electronic e-mail, mobile phones Fax (Scott 2004). These also have features of speed, accuracy, wider reach and time conservation to the barest minimum in the transfer and retrieval of information (Adeogun 2003). The world is today referred to, as a global village.

The benefits of ICT to Libraries and Librarians are innumerable as have been variously stated and discussed by Mohammed (1999), INASP (2003), and Adomi et al (2004). Nwalo (2000) listed some of the benefits to Libraries as, been able to automate technical services, to provide efficient reference and information services, to network operations such as cataloguing, authority control, inter Library loans, and international bibliographic projects. Cochrane (1992) also pointed out the elimination of uninteresting and repetitive Library duties, increasing range of services offered, and providing marketing opportunities. Dilevko and Herris (1997) report that the traditional Library practice is undergoing significant changes due to the electronic revolution introduced into Library scence.

On the other hand, Abdulganiy (2000) point out that the revolution opens "new vistas to Librarians and information specialists which can however not be fully exploited if there is no corresponding adequate level of computer literacy amongst Library staff, Krissoff and Konrad (1998).

To successfully exploit ICT for full benefits, Marmwin (1998) advices that Librarians must develop expertise in and establish programme of knowledge search and management in support of clientele needs. They must also cultivate the technical capability and subject knowledge which they effectively exploit to meet the information needs of their clientele. According to Ikpahindi (1999), skills acquisitions requirements are in the basic areas of the knowledge of the computers; how it functions, imputing and retrieval of information from it, ability to analyze the Library situation for proposal for automation, ability to choose appropriate software, ability to organize, capture and use ICT based resources. It also includes ability to carry out searches on CD-ROMS and searches on Public Access Catalogues OnLine. Other skills considered relevant for the Librarian of today as enunciated by Morgan (1998), are elementary programming in one or two web languages, communication skills, database creation and the basic knowledge of how to use Fax, e-mail equipment as well as downloading of mails from the Internet. These benefits can however only be appropriated and exploited in the libraries if librarians themselves are literate in information and communication technology. As stated by Krissof and Konrad (1998), "full ICT implementation in a library largely depends on the attitude and knowledge of Library staff.

The result of Adeyoyin's survey of 18 Universities in Nigerian reveals that only 32\% of professional Libraries so far in Nigeria were ICT literate. Adeyoyin (2005), It is this observable lack of ICT knowledge among professional librarians and; this is almost eighteen years after a previous Gupta and Ubogu revealed this weakness, that prompts Johnson (1998), Nwalo (2000), Oketunji (2000), and Mabawouku 2005 to advocate a serious examination and possible overhauling of the Library School Curriculum to include ICT study/teaching. They advocated these new crop of Librarians would therefore be literate and ICT competent to handle the information work in the Libraries of the $21^{\text {st }}$ Century.

The call on librarians for retraining to become ICT literate and competent is a continuous one which will from time to time be tested by an evaluation of the literacy and competency level of practicing librarian. This therefore, is focus of this study. It is a self evaluation survey design to ascertain the levels of ICT knowledge and competency of practicing Librarians in Delta State.

\section{OBJECTIVES}

The objectives of this study are:-

- To determine the level of ICT literacy among practicing librarian in Delta State.

- To determine the level of ICT compliance in libraries in the State.

- And to determine the challenges of ICT application in the State.

- To make recommendation.

\section{METHODOLOGY}

The study employed the questionnaire method as survey instrument. It was also designed as a self assessment instrument for the individual librarian.19 institutional libraries with a total of 104 librarians were issued questionnaires see table. 
The libraries are academic/public libraries. There was no distinction between the different types of libraries, no distinction between the different classes or levels of librarians. All librarians practicing in the different libraries listed were eligible and used for the study. The questionnaire contained nine self assessment questions.

FINDINGS

\begin{tabular}{|c|c|c|c|c|c|c|}
\hline & & \multicolumn{5}{|c|}{ NO. OF ICT LITERATES } \\
\hline Name of Institutions & $\begin{array}{l}\text { No. of } \\
\text { Librarians }\end{array}$ & $\begin{array}{l}\text { On-line } \\
\text { Network }\end{array}$ & Internet & E-mail & $\begin{array}{c}\text { Mobile } \\
\text { Telephoning }\end{array}$ & $\begin{array}{l}\text { Fax } \\
\text { Machine }\end{array}$ \\
\hline DELSU, Abraka & 16 & 2 & 16 & 16 & 16 & 2 \\
\hline DELSU, Asaba & 3 & 0 & 3 & 3 & 3 & 0 \\
\hline DELSU, Oleh & 3 & 0 & 3 & 3 & 3 & 0 \\
\hline DELSP, Polythenic, Ozoro & 5 & 0 & 5 & 5 & 5 & 2 \\
\hline $\begin{array}{lll}\text { DELSP, } & \text { Polythenic } \\
\text { Ogwashaku } & \end{array}$ & 3 & 2 & 3 & 3 & 3 & 2 \\
\hline $\begin{array}{l}\text { DELSP, Polythenic - Otefe- } \\
\text { oghara }\end{array}$ & 3 & 0 & 3 & 3 & 3 & 1 \\
\hline $\begin{array}{l}\text { Federal College of Edu., Asaba } \\
(\mathrm{Tec})\end{array}$ & 3 & 0 & 3 & 3 & 3 & 0 \\
\hline College of Education - Agbor & 3 & 0 & 0 & 2 & 3 & 1 \\
\hline College of Education - Warri & 2 & 0 & 2 & 2 & 2 & 2 \\
\hline P.T.I - Effurun & 8 & 8 & 8 & 8 & 8 & 8 \\
\hline $\begin{array}{l}\text { College of Physical Edu. - } \\
\text { Mosogan }\end{array}$ & 2 & 0 & 2 & 2 & 2 & 2 \\
\hline School of Health - Ufuoma & 1 & 0 & 0 & 0 & 1 & 0 \\
\hline N.N.P.C. - Zonal Warri Office & 1 & NA & NA & NA & NA & NA \\
\hline P.P.M.C, Warri & 1 & NA & NA & NA & NA & NA \\
\hline House of Assembly & 1 & 0 & 1 & 1 & 1 & 1 \\
\hline $\begin{array}{l}\text { Ministry of information - } \\
\text { Asaba }\end{array}$ & 1 & 0 & 1 & 1 & 1 & 1 \\
\hline Ministry of Justice - Asaba & 1 & 1 & 1 & 1 & 1 & 1 \\
\hline NTA - Library Asaba & 1 & 0 & 1 & 1 & 1 & 1 \\
\hline Delta Library Board & 46 & 6 & 14 & 14 & 46 & 4 \\
\hline TOTAL & 104 & 19 & 66 & 68 & 104 & 28 \\
\hline
\end{tabular}

NA $=$ NOT AVAILABLE

FORMS OF ICT POPULAR AMONG LIBRARIANS 
Data reveals that the need for communication is stronger than any other driving forces in the use of ICT among Librarians. As such; mobile telephones 100\%, e-mail $60 \%$ are more commonly in use. The internet also attracts much use $63.5 \%$. This was not a surprise, as browsing and accessing specific websites is needed for information and research purposes. Other ICT gadgets like on-line and use of fax machines do not attract much use $19 \%$ and $27 \%$ respectively. The reasons are not too obvious. One may however point to the fact that the need for their use does not exist or it's minimal, or they are simply not available in the libraries.

The study also revealed that only very few Librarians (those in some special Libraries) had and applied ICT in their official assignments that is; had computerized and networked offices. Most Libraries (Public, academic and some special Libraries) are yet to catch on the ICT train. Library work and services are still been operated in the traditional way. The result is that Librarians do not get to use ICT except for personal jobs and services and that is outside the library. It will be safe to infer that librarians in the State are yet to achieve a desirable competency level in ICT knowledge and skills acquisition.

The data generated also reveal that some Librarians are qualified ICT personnel either with a certificate or Diploma. A total of 42 Librarians hold either of these qualifications and therefore term themselves as ICT literate. Others though ICT literate to varying degrees, do not have any certificate to show. These groups learn and practice on their PCs or in the cyber cafés with the help of the attendants and ICT assistants in the Cafes. The training gotten from these sources are only minimal as, Librarians surveyed agreed that they were only familiar with very basic operations that can see them through getting what they wanted for the moment e.g. sending or receiving e-mail, assessing specific web-sites and general browsing of the web.

\section{FACTORS INHIBITING THE USE OF ICT AMONG LIBRARIANS}

Various reasons have been adduced for the lack of full exploitation of ICT in Nigeria. The works of Ikpahindi (1999), Mohammed (1999), Nwalo (2000), Oketunji (2000), and Adomi (2004), all reveal that lack of technical manpower, equipment and costs, lack of constant electricity supply and lack of the full installation of ICT in Nigeria inhibit the application and use of ICT in Nigeria. Though the situation can be said to have improved especially because of the private sector initiative (most cyber cafés are privately owned) and the liberalization of telecommunication sector, there still exists inhibitors that need to be removed.

The first major of these, is the apathy, lack of will and the absence of policy on implementation of ICT in libraries and other government offices by the government. In some cases, computers are acquired and that is all. The next phase of actual computerization and internet connectivity is left hanging. The result is that most of the computers are used only or word processing. Since computerization with all other ICT complements are capital intensive, it behooves on the State government to pencil it down as a capital project to be vigorously pursued to a successful end. Libraries are the knowledge gateway for the society. What services can the public library without ICT possibly render today? The immediate danger facing the society is that Libraries are shunned of cyber cafés where access to information is not regulated or guided. This fear was expressed by Lesk (1995) who posited that librarians must be familiar with how to access information from the web or face the risk of being bypassed. As posited by Taylor (1986), repacking of analysed and evaluated information adds value to the information. This is the job of librarians using ICT. What quality of education and research support can academic libraries without ICT provide to their institutional goals and objectives? Though cyber cafés dot University Campuses and towns, their ability to offer quality reference and bibliographic services are in serious doubt only. Librarians are better positioned to offer proper guide through the maze of information on the web (Ugboma) (2005), Johnson (1998).

This discourse cannot and without a critical look at the practicing Librarian. This study revealed that most Librarians are still ICT shy. The simple deductive reason is that ICT is not provided to do the job. This observable lack of interest or slow rate of response to ICT knowledge and skills is responsible for the low rate of ICT application and use in Libraries. The onus however rests on the librarians not to only create the awareness of ICT, but also embark on a systematic and focused drive for ICT acquisition in their libraries. Could heads of libraries not carve out a deliberate policy of ICT implementation and pursue it with their 
budgetary allocations? It is clear from literature that Librarians can no longer entertain the notion of full acquisitions of all that is published today, neither can they wait for others to show them the way to adequate and efficient information service delivery. They have the requisite skills and possess the knowledge to handle information delivery for the society, inhibitions not withstanding. The $21^{\text {st }}$ century Librarians must be ICT literate to fully exploit them for their clientele.

\section{NEW DEVELOPMENT}

It behooves on this study to point to new development in the information market that can be exploited for the benefit of libraries.

In 2003, the Federal Government reached an agreement with UNESCO to help develop virtual libraries for higher institutions in the country. This was designed to the Nigerian academic the opportunity of access to academic publication especially Journals through. WWW.nig@nalibrary.net.This development is a signal to every librarian to prepare for a more cost efficient and cost effective method of rendering information services.

Some Universities in Nigeria have also designed viable project of sharing and shedding cost for the provision of virtual library services for their institutions. The Delta State University for example, reached agreement with Oceanic bank Plc to sponsor and provide e-learning and e-banking services on campus for a fee to student. This service is also expected to extend to the library by the provision of radios and computer workstations at least (4 PCs). It is expected that users could also go on-line and into the Internet at the cost of five thousand Naira ( $\$ 5,000.00)$ a session charged to school fees. Today, students can conduct their educational pursuits within the campus.

Some other universities got international sponsorship for ICT installation and management. The law faculty library of the University of Jos which is sponsored by the Carnegie Cooperation is an example. Public, special and other academic libraries can take a hint and begin to seek for sponsors and corporations to provide virtual library services for their libraries.

\section{CONCLUSIONS AND RECOMMENDATIONS}

The research concern of this study has been to show that Librarians who are in the vanguard for the acquisition and use of ICT are themselves ready. The major findings reveal that respondents

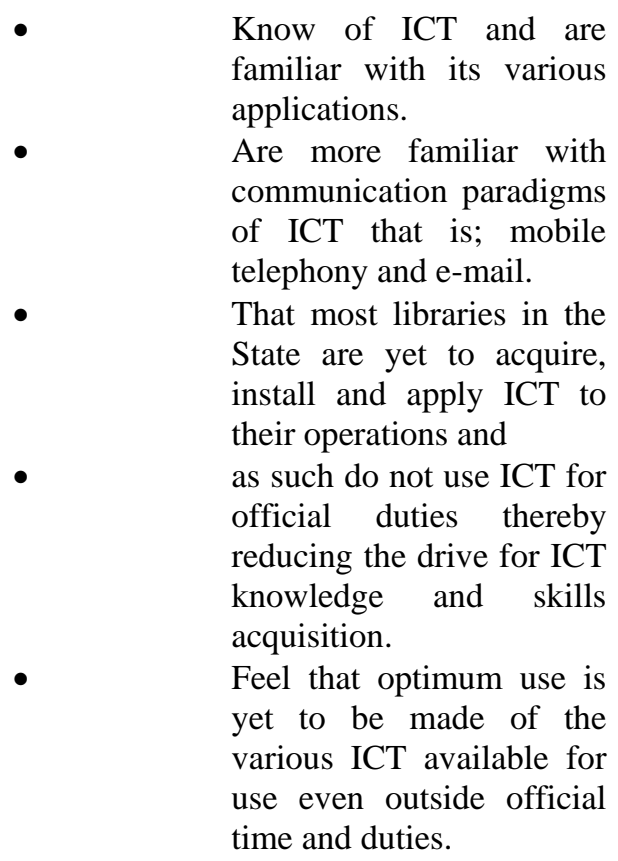

The current global effects of the discovery of the information super-highway makes it mandatory for countries, government and people especially Librarians to conduct a re-appraisal, for better, more effective that is; positioning policies as it affects knowledge acquisition. Information is power. For a country to be socially and economically strong, it must have valuable information. This is the whole reason why ICT is not optional. As information professionals, Librarians must consciously work towards achieving a rich information environment. This is only possible through ICT. following:-

This study therefore, recommends the

All Libraries in the State, academic, special and public Libraries should present a position paper on ICT for Libraries to the State government.

That libraries, through the umbrella of the Nigeria Libraries Association should go into partnership with national and international organizations are interested in ICT development in Africa to help develop ICT in designated Libraries in the State. This avenue has already been explored by the Federal Government who got UNESCO to help it develop virtual library for higher institutions in the country. (The virtual library project was commissioned in March 2003 by the National Universities Commission. (NUC)\}.

This study also recommends the compulsory exposure of Librarians to ICT 
knowledge and skills. It is recommended that Librarians should register for ICT training with recognized institutions to ensure maximum benefit, at the end of which they could get a diploma or degree certificate. Skills and knowledge required are competence in internet applications, search engines, electronic information sources, and digital library services.

The importance of ICT in libraries is innumerable and as stated by Lesk (2005), "Libraries cost more to build than the setting up of a virtual library and its housing". The importance of Librarians being ICT literate therefore speak for itself.

\section{REFERENCE}

Adoyoyin, Samuel (2005) Information and communication technology (ICT) literacy among the staff of Nigerian University Libraries. Library Review Vol. 54 No. 4.

Adeogun, m (2003) "The digital divide and University education systems in sub-Saharan Africa”. African Journal of Library Archives and Information Science 13 (1).

Adomi, E.E., Omodeko, F.S. and Otolo, P.U. (2004) "Use of Cybercafe at Delta State University, Abraka, Nigeria” Library Hi-tech, 22 (4).

Cochrane, P.A (1992) “Information technology in Libraries and Ranganathans five laws of library Science Libri 42 (3).

Dilevko, J. and Harris, R.M. (1997) "Information technology and social relations". Journal of the American Society for information Science. Vol. 48.

Ifidon, S.E. (2003) "Information superhiwayaccess to research resources in Nigerian State Universities" Social and management science review 1 (1).

Ikpahindi, L. N (1999) Essential knowledge-base for information science and technology libraries in a democratic culture. Information for the substance of democratic culture: Paper; NLA Annual National Conference and AGM.

Internal Network for the availability of scientific Publication (INASP) (2003) “Optimizing Internet bandwidth in developing countries higher education” INASP infobrief 1 July.
Available at: WWW.INASP: Info/pubs/band width/bandwidth-infobrief-funal.pdf.

Johnson, I. M. (1998) "Challenges in developing professionals for the information society” and some responses by the British Schools of librarianship and information studies. Library Review Vol. 47 No. 3.

Krissoff, A and Konrad, L (1998) "Computer training for staff and patrons" Computers in libraries, Vol 18 No. 1.

Lesk, M. (1995) “Libraries and web.” Available @ http:/WWW.

Mabawonku, I (2005) Training for the library and information profession in Nigeria: an overview of recent developments at the University of Ibadan Library School. Paper: NLA Conference and AGM Abeokuta.

Marmwin, D (1998) "Facing the challenge: Technology training in Libraries," Information technology and Libraries. December.

Modu, E.C. and Adeniran, T.N (2000) "Information Technology: Uses and preservation of Resources in Libraries and Information Centres, Odumat, Oyo.

Mohammed, Z (1997) Funding Nigeria libraries and Information Centres: challenges of the $21^{\text {st }}$ C. Paper: NLA Conference and AGM, Kaduna.

Morgan, E. L. (1998) “Computer literacy for librarians” Computers in Libraries. Vol.18 No. 1.

Nwalo, K.N (2000) Collaboration in the provision and utilization of IT facilities for library and information science education in Nigeria. Paper presented at $10^{\text {th }}$ Biennial Conference of the National Association of Library and Information Education NALISE, Ibadan.

Nweke, K.M.C (1992) "Information technology in Nigerian Special Libraries “. In Adeyoyin, S.D, Information and communication technology (ICT) Literacy among the staff of Nigeria University Libraries. Library Review Vol. 54 No. 4.

Oketunji, I. (2000) “Application of Information Technologies in Nigerian Libraries: Problems and Prospects. Paper: $10^{\text {th }}$ Biennial Conference 
of the National Association of Library and Information Educations, NALISE, Ibadan.

Taylor, R.S. (91986) Valve Added Process in Information System. Ablex Publishing, New Jersey, M.3 quoted in Johnson, I. M. Challenges in developing professionals for the "Information Society" and some responses by the British Schools of librarianship and information studies. Library Review Vol. 47 No.3
Scott, N (2004) Africa's New Communications users- what do they use and why? Available at. WWW.balancingact-

africa.com/news/back/balancingact.147.htm/.

Ubogu, F.N and Gupta, D.K (1987) Mini and Micro- computers: under-use and possible use in Nigerian libraries, documentation and Information Centres”. Nigerbiblios, Vol. 12.2

Ugboma, M. U. (2005) The law librarian and globalization: Prospects and Challenges. Communicate Vol.7 No 1.12. 